\title{
EKSTRAK BUAH NANAS TERHADAP JUMLAH TOTAL LEUKOSIT DAN NEUTROFIL IKAN LELE (Clarias batrachus) YANG DIINFEKSI DENGAN Aeromonas hydrophila
}

\author{
Ratna Widyawati ${ }^{1}$, Dhia Nadhifa ${ }^{1}$, Dyah Widhowati ${ }^{{ }^{*}}$ \\ ${ }^{1}$ Fakultas Kedokteran Hewan, Universitas Wijaya Kusuma Surabaya \\ *Email : dyahwidho@gmail.com
}

\begin{abstract}
The present research to determine the Extract of Pineapple (Ananas comosus) on the survival of catfish infected with A. Hydrophila. The main problem of cultivation of catfish (C. batrachus) is a disease caused by the bacterium Aeromonas hydrophila.Catfish (Clarias batrachus) is a freshwater fish that has several advantages, one of which is a high nutritional content. Test animals used were catfish measuring 15-20cm with a body weight of $\pm 250 \mathrm{gr}$. Challenge test by injecting A. hydrophila suspension with a dose of $10^{8} \mathrm{sel} / \mathrm{mm} 3$ as much as $0.1 \mathrm{~mm}$ intramuscularly. Observations were made for 7 days after infection which included the total number of leukocytes and neutrophils. This study was divided into 5 treatment groups with 5 replications, namely P1 (positive control), P2 (0.1\%), P3 (0.3\%), P4 (0.5\%), P5 (0.7\%) and soaking Pineapple Fruit Extract for 24 hours. Data analysis in this study used one way ANOVA statistical test. The results showed symptoms of catfish attacked by Aeromonas hydrophila including increased total number of leukocytes and neutrophils and ulceration in catfish. Soaking effect Pineapple fruit extract $0.5 \%$ effective dose can reduce the total number of leukocytes and $0.7 \%$ effective dose can reduce the total number of neutrophils.
\end{abstract}

Keywords : Aeromonas hydrophila, catfish, leukocytes, neutrophils, pineapple

\section{PENDAHULUAN}

Ikan Lele (Clariasbatrachus) merupakan Ikan air tawar yang sangat populer dan diminati oleh masyarakat luas. Ikan Lele (C.batrachus) juga memiliki beberapa kelebihan diantaranya adalah pertumbuhan yang cepat, memiliki kemampuan beradaptasi terhadap lingkungan yang tinggi, sehingga di lahan dan sumber air yang terbatas Lele dapat dibudidayakan, rasanya yang enak, dan kandungan gizinya yang terbilang tinggi. Salah satu penyakit yang dapat menginfeksi dan menyebabkan kematian Ikan Lele (C.batrachus) adalah penyakit MAS (Motile Aeromonas Septicemia) yang disebabkan oleh bakteri Aeromonas hydrophila.Bakteri Aeromonas hydrophila adalah bakteri oportunistik, dimana bakteri ini akan menyerang tubuh saat sistem kekebalan tubuh menurun, sehingga bakteri ini memiliki kesempatan untuk menginfeksi tubuh.
Aeromonas hydrophila termasuk dalam bakteri gram negatif, dan dapat menyebabkan kematian Ikan dalam waktu yang sangat singkat hingga mencapai 80-100\% (Muslikha, Pujiyanto, Jannah, \& Novita, 2016). Pemanfaatan tumbuhan dan buah untuk pengobatan herbal dengan berbagai macam metode yang dapat dilakukan. Salah satunya adalah buah Nanas.

Buah yang memiliki nama latin Ananascomosus merupakan salah satu jenis buah asal daerah tropis yang mempunyai nilai ekonomis dapat diolah menjadi olahan pangan. Bonggol Nanas mengandung beberapa bahan kimia yang berfungsi sebagai desinfektan dan memiliki daya hambat bakteri (Marlina dkk, 2018). Bahan aktif yang terkandung dalam buah nanas adalah senyawa tannin, flavonoid, dansaponin. Tannin merupakan senyawa yang termasuk dalam golongan fenol. Mekanisme kerja tannin sebagaian timikroba yaitu dengan menginaktivasi adhesi sel mikroba. Tannin dapat menyebabkan pengerutan pada dinding 
e-ISSN 2685-8894; p-ISSN 2460-9773

Jurnal Vitek Bidang Kedokteran Hewan Vol.10, November 2020

sel bakteri sehingga akan mengganggu permeabilitas sel dan akan menyebabkan terganggunya hidup sel, dan menghambat sintesis asam nukleat sehingga pertumbuhan bakteri dapat terhambat (Putri dkk, 2016).

\section{Hipotesis}

$\mathrm{H}_{0}$ : Tidak terdapat pengaruh dari pemberian Ekstrak Buah Nanas pada jumlah total leukosit dan neutrofil pada darah Ikan Lele (Clarias batrachus) yang diinfeksi Aeromonas hydrophila.

$\mathrm{H}_{1}$ : Terdapat pengaruh dari pemberian Ekstrak Buah Nanas pada jumlah total leukosit dan neutrofil pada Ikan Lele (Clarias batrachus) yang diinfeksi Aeromonas hydrophila.

\section{METODE PENELITIAN}

\section{Materi Penelitian Alat Penelitian}

Alat yang digunakan pada penelitian ini adalah syringe $1 \mathrm{cc}$, syringe $3 \mathrm{cc}$, selang oksigen, aerator oksigen, aquarium, tabung heparin, beaker glass, object glass, cover glass, kamar hitung, mikroskop, glove, bunsen, korek api, rak pewarnaan, pipet tetes, pipet thoma leukosit, trash bag, tisu kering, evaporator vaccum, kertas saring WH40, shaker

\section{Bahan Penelitian}

Bahan yang digunakan pada penelitian ini adalah Buah Nanas (Ananas comosus) yang dibeli dipetani Nanas di Wilayah Gunung Kelud Kediri Jawa Timur, Ikan Lele (C.batrachus) sebanyak 25 ekor, Aeromonas hydrophila dengan dosis $10^{8} \mathrm{sel} / \mathrm{mm}^{3}$ sebanyak $0,1 \mathrm{~mL}$ per ekor, air sebanyak 20L, pakan Ikan Lele $(C$. batrachus), sample darah Ikan Lele ( $C$. batrachus), heparin, aquadest, methanol 95\%, pewarna giemsa, larutan Turk, etanol $96 \%$.

\section{Metode Penelitian Jenis Penelitian}

Jenis penelitian ini adalah penelitian eksperimental dengan menggunakan Rancangan Acak Lengkap ( RAL ). Dalam penelitian ini digunakan 25 ekor Ikan Lele yang dibagi menjadi 5 kelompok perlakuan dan 5 ulangan.

\section{Variable Penelitian}

Variabel penelitian ini terdiri dari 3 Buah yaitu Variabel Bebas : Pemberian Ekstrak Buah Nanas.

Variabel Tergantung : Jumlah total Leukosit dan Neutrofil dalam darah Ikan Lele (Clariasbatrachus) yang diinfeksi A. Hydrophila dan diberi perasan Ekstrak Buah Nanas.

Variabel Kendali : Cara pemberian Ekstrak Buah Nanas, jenis pakan, suhu, kondisi lingkungan, ukuran dan berat Ikan Lele (C.batrachus).

\section{Analisis Data}

Data hasil pemeriksaan gambaran darah dianalisis menggunakan Analalysis of Varians (ANOVA) atau uji F. Perbedaan dalam masingmasing perlakuan dilanjutkan dengan uji Duncan

\section{HASIL}

Hasil penelitian sampel darah Ikan Lele (Clarias batrachus) dalam keadaan sehat, lalu setelah diinfeksi dengan Aeromonas hydrophilla dan setelah diberi perendaman Ekstrak Buah Nanas dengan konsentrasi berbeda setiap kelompok, yaitu pada P1 (tanpa perendaman Ekstrak Buah Nanas), P2 (Ekstrak Buah Nanas 0,1\%), P3 (Ekstrak Buah Nanas 0,3\%), P4 (Ekstrak Buah Nanas 0,5\%), P5 (Ekstrak Buah Nanas 0,7\%) pada jumlah total leukosit dan jumlah total neutrofil dengan pengolahan data statistik ANOVA. Dapat dilihat pada tabel berikut : 
e-ISSN 2685-8894; p-ISSN 2460-9773

Jurnal Vitek Bidang Kedokteran Hewan Vol.10, November 2020

\section{Leukosit}

Tabel 1 Rata-rata jumlah leukosit Ikan Lele (Clarias batrachus) sebelum dan sesudah infeksi bakteri Aeromonas hydrophilla.

\begin{tabular}{ccc}
\hline No & $\begin{array}{c}\text { Infeksi } \\
\text { Aeromonas } \\
\text { hydrophila }\end{array}$ & $\begin{array}{c}\text { Leukosit } \\
\left(\mathbf{x 1 0} \mathbf{s e l}^{\mathbf{3}} \mathbf{\mathrm { mm }} \mathbf{m m}^{\mathbf{3}}\right) \\
\text { Mean } \pm \text { SD }\end{array}$ \\
\hline $\mathbf{1}$ & $\begin{array}{c}\text { Sebelum infeksi } \\
\text { Aeromonas hydrophila }\end{array}$ & $7.50 \pm 2.07$ \\
\hline 2 & $\begin{array}{c}\text { Sesudah infeksi } \\
\text { Aeromonas } \\
\text { hydrophila }\end{array}$ & $\mathbf{1 3 . 2 1} \pm$ \\
& $\mathbf{4 , 2 9}$ \\
\hline
\end{tabular}

Keterangan: Sumber data primer yang diolah, nilai rata-rata pada kolom yang tidak sama menunjukkan Jumlah total leukosit Ikan Lele (Clarias batrachus) sebelum dan setelah diinfeksi Aeromonas terdapat perbedaan sangat nyata $(\mathrm{P}<0.01)$.

Tabel 2. Rata-rata jumlah leukosit Ikan Lele (Clarias batrachus) terhadap pengaruh perendaman Ekstrak Buah Nanas.

\begin{tabular}{|c|c|c|}
\hline No & Perlakuan & $\begin{array}{c}\text { Leukosit }\left(\mathrm{x10}^{3} \mathrm{Sel} / \mathrm{mm}^{3}\right) \\
\text { Mean } \pm \text { SD }\end{array}$ \\
\hline 1 & $\begin{array}{l}\text { P1 } \\
\text { Tanpa } \\
\text { Ekstrak } \\
\text { Nanas }\end{array}$ & $17.46 \pm 3.35^{\mathrm{a}}$ \\
\hline 2 & $\begin{array}{c}\text { P2 Ekstrak } \\
\text { Nanas }(0.1 \%)\end{array}$ & $8.24 \pm 3.24^{b}$ \\
\hline 3 & $\begin{array}{c}\text { P3 Ekstrak } \\
\text { Nanas }(0.3 \%)\end{array}$ & $7.87 \pm 1.67^{c}$ \\
\hline 4 & $\begin{array}{c}\text { P4 Ekstrak } \\
\text { Nanas }(0.5 \%)\end{array}$ & $7.66 \pm 1.21^{\mathrm{d}}$ \\
\hline 5 & $\begin{array}{c}\text { P5 Ekstrak } \\
\text { Nanas (0.7\%) }\end{array}$ & $10.10 \pm 3.06^{\mathrm{e}}$ \\
\hline
\end{tabular}

Keterangan: Sumber data primer yang diolah , nilai rata-rata pada kolom yang tidak sama menunjukkan Jumlah total leukosit Ikan Lele (Clarias batrachus) dengan perendaman Ekstrak Buah Nanas terdapat perbedaan sangat nyata $(\mathrm{P}<0.01)$.

Superskrip (a, b, c, d, e) P1 dengan nilai $17.46 \times 10^{3} \mathrm{Sel} / \mathrm{mm}^{3} \pm 3.35$ terdapat perbedaan sangat nyata dengan P2 dengan nilai 8.24 $\mathrm{x} 10^{3} \mathrm{Sel} / \mathrm{mm}^{3} \pm 3.24$. P2 berbeda nyata dengan $\mathrm{P} 37.87 \times 10^{3} \mathrm{Sel} / \mathrm{mm}^{3} \pm 1.67$. P3 berbeda nyata dengan P4 $7.66 \times 10^{3} \mathrm{Sel} / \mathrm{mm}^{3} \pm 1.21$. P4 berbeda nyata dengan P5 $10.10 \times 10^{3} \mathrm{Sel} / \mathrm{mm}^{3}$ \pm 3.06 . Data memiliki perbedaan yang sangat nyata antara jumlah total leukosit pada Ikan Lele P1(tanpa Ekstrak Buah Nanas) sebagai kontrol positif dengan $\mathrm{P} 2(0.1 \%)$, $\mathrm{P} 3(0.3 \%)$, P4(0.5\%), P5(0.7\%).

\section{Neutrofil}

Tabel 3. Rata-rata jumlah total neutrofil Ikan Lele (Clarias batrachus) sebelum dan sesudah diinfeksi Aeromonas hydrophilla

\begin{tabular}{ccc}
\hline No. & Infeksi Aeromonas & Neutrofil \\
& hydrophila & Mean \pm \\
& & SD \\
\hline 1 & Sebelum diinfeksi & $2.64 \pm$ \\
& Aeromonas hydrophila & 1.46 \\
\multirow{2}{*}{2} & Sesudah diinfeksi & $7.40 \pm$ \\
& Aeromonas hydrophila & 4.46 \\
\hline
\end{tabular}

Keterangan: Sumber data primer yang diolah , nilai rata-rata pada kolom yang tidak sama menunjukkan Jumlah total leukosit Ikan Lele (Clarias batrachus) sebelum dan setelah diinfeksi Aeromonas terdapat perbedaan sangat nyata $(\mathrm{P}<0.01)$.

Tabel 4.Rata-rata jumlah total neutrofil Ikan Lele (clarias batrachus) dengan perendaman Ekstrak Buah Nanas

\begin{tabular}{|c|c|c|}
\hline No & Perlakuan & $\begin{array}{c}\text { Neutrofil } \\
\left(\times 10^{3} \text { Sel/mm }\right. \\
\left.{ }^{3}\right) \\
\text { Mean } \pm \\
\text { SD }\end{array}$ \\
\hline 1 & $\begin{array}{c}\text { P1 Tanpa Ekstrak } \\
\text { Nanas }\end{array}$ & $\begin{array}{c}8.80 \pm \\
4.08^{\mathrm{a}}\end{array}$ \\
\hline 2 & $\begin{array}{c}\text { P2 Ekstrak Nanas } \\
(0.1 \%)\end{array}$ & $\begin{array}{c}4.80 \pm \\
4.32^{\mathrm{b}}\end{array}$ \\
\hline 3 & $\begin{array}{c}\text { P3 Ekstrak Nanas } \\
(0.3 \%)\end{array}$ & $\begin{array}{c}2.20 \pm \\
1.78^{\mathrm{c}}\end{array}$ \\
\hline 4 & $\begin{array}{c}\text { P4 Ekstrak Nanas } \\
(0.5 \%)\end{array}$ & $\begin{array}{c}3.80 \pm \\
3.56^{\mathrm{d}}\end{array}$ \\
\hline 5 & $\begin{array}{r}\text { P5 Ekstrak } \\
\text { Nanas } \\
(0.7 \%)\end{array}$ & $\begin{array}{c}1.40 \pm \\
0.54^{\mathrm{e}}\end{array}$ \\
\hline
\end{tabular}


e-ISSN 2685-8894; p-ISSN 2460-9773

Jurnal Vitek Bidang Kedokteran Hewan Vol.10, November 2020

Keterangan: Sumber data primer yang diolah, nilai rata-rata pada kolom yang tidak sama menunjukkan Jumlah total neutrofil Ikan Lele (Clarias batrachus) dengan perendaman Ekstrak Buah Nanas berbeda nyata ( $\mathrm{P}>0.05)$.Superskrip (a, b, c, d, e) P1 dengan nilai $8.80 \pm 4.08$ berbeda nyata dengan P2 dengan nilai $4.80 \pm 4.32$. P2 berbeda nyata dengan P3 dengan nilai $2.20 \pm 1.78$. P3 tidak berbeda nyata dengan $\mathrm{P} 4$ dengan nilai $3.80 \pm$ 3.56. $\mathrm{P} 4$ berbeda nyata dengan $\mathrm{P} 5$ dengan nilai $1.40 \pm 0.54$. Data memiliki perbedaan nyata antara jumlah total Neutrofil P1(tanpa Ekstrak Buah Nanas) sebagai kontrol positif dengan P2(0.1\%), P3(0.3\%), P4(0.5\%), P5(0.7\%).

\section{PEMBAHASAN}

Leukosit adalah komponen darah yang berperan penting dalam memerangi infeksi yang disebabkan oleh bakteri, virus, maupun proses metabolik toksin, dan lain-lain. Nilai normal leukosit berkisr $3390-14200 / \mathrm{mm}^{3}$ dan nilai normal pada neutrofil berkisar 3.256.40\%.Penurunan kadar komponen leukosit bisa ditemukan pada kasus penyakit akibat infeksi virus, penyakit sumsum tulang, dan lain-lain, sedangkan peningkatannya bisa ditemukan pada penyakit infeksi bakteri, penyakit inflamasi kronis, pendarahan akut, leukemia, gagal ginjal, dll. Peningkatan jumlah leukosit menunjukkan adanya respon perlawanan tubuh terhadap agen penyakit, Ikan yang sakit akan menghasilkan banyak leukosit untuk memfagositosis bakteri dan mensintesis antibodi (Mahasri dkk, 2011).

Pada penelitian kali ini hewan yang digunakan yaitu Ikan Lele (Clarias batrachus) dengan berat badan \pm 250 gr dan panjang sekitar $15-20 \mathrm{~cm}$. Pengobatan merupakan alternatif terakhir setelah upaya pencegahan gagal dilakukan. Hal-hal yang perlu diperhatikan sebelum melakukan pengobatan adalah ketepatan diagnosa penyakit, jenis dan dosis efektif obat atau antibiotik, kemudahan memperoleh obat dan harga, waktu luruh obat yang pendek, kemungkinan keberhasilan pengobatan, teknik aplikasi yang hendak diterapkan.

Teknik aplikasi pengobatan ada beberapa metode, metode pertama melalui perendaman dibagi menjadi tiga cara yang dibedakan dari dosis obat, yang pertama pencelupan dimana cara ini dilakukan pada dosis obat yang tinggi selama beberapa detik, yang kedua perendaman jangka pendek (short bath) dimana pengobatan ini dilakukan pada dosis obat yang relatif tinggi selama beberapa menit, yang ketiga perendaman jangka panjang (long bath)dimana pengobatan ini umumnya dilakukan di akuarium atau kolam lain selama beberapa jam atau hari. Metode kedua melalui pakan, pengobatan melalui pakan lebih sedikit menimbulkan stress pada Ikan dan hanya efektif pada tahap awal infeksi, dimana Ikan masih memiliki nafsu makan. Metode ketiga dengan aplikasi langsung ke tubuh Ikan yang dibagi menjadi dua cara yaitu penyuntikan yang terutama untuk Ikan ukuran besar, memiliki keuntungan penggunaan obat yang sangat efisien dan cepat, ada dua cara penyuntikan yaitu dengan cara diinjeksikan ke rongga perut (intra perioneal) dan diinjeksikan ke otot (intra muskular), cara lain dari metode aplikasi langsung ke tubuh Ikan adalah dioleskan, teknik ini umumnya dilakukan pada Ikan sakit yang memiliki gejala klinis yang sangat nyata misalnya luka atau ulser.

Hasil uji analisis statistik saat sebelum dan sesudah diinfeksi Aeomonas hydrophila pada jumlah total leukosit dan neutrofil terdapat perbedaan sangat nyata $(\mathrm{P}<0.01)$. Jumlah total leukosit sebelum dan sesudah terinfeksi Aeromonas hydrophilaberturut turut adalah jumlah leukosit normal yaitu, 3.39- 
e-ISSN 2685-8894; p-ISSN 2460-9773

Jurnal Vitek Bidang Kedokteran Hewan Vol.10, November 2020

$14.20 \times 10^{3} / \mathrm{Sel} / \mathrm{mm}^{3}$. Sehingga jumlah total leukosit antara Ikan Lele sebelum dan sesudah diinfeksi dengan Aeromonas hydrophila mengalami kenaikan, yang mengindikasikan ikan mengalami infeksi yang disebabkan oleh bakteri Aeromonas hydrophila (Purnamasairi, Sasanti, \& Yulisman, 2015). Jika jumlah leukosit naik dan disebabkan oleh bakteri maka akan berkolerasi dimana jumlah total neutrofil juga akan naik setelah terinfeksi dengan bakteri Aeromonas hydrophila. Data jumlah neutrofil Ikan Lele sebelum dan sesudah terinfeksi dengan Aeromonas hydrophila, jumlah total neutrofil normal Ikan yaitu 3.25-6.40\%, sehingga jumlah total neutrofil antara Ikan sebelum dan sesudah terinfeksi Aeromonas hydrophila menunjukkan kenaikan diatasnormal yang mengindikasikan Ikan Lele terinfeksi oleh bakteri (Salasia dkk, 2001).

Terjadi peningkatan pada leukosit setelah Ikan Lele diinfeksi dengan bakteri Aeromonas hydrophila, mengalami kenaikan tetapi masih belum melampaui kadar normal yaitu 13,21 (10 $\wedge 3 / \mu 1)$, dan neutrofil melebihi nilai normalyaitu 7.40\%. Setelah dilakukan perendaman dengan Ekstrak Buah Nanas, dimana leukosit Ikan Lele turun pada P2 $(0.1 \%)$, P3 $(0.3 \%)$, dan P4 (0.5\%). Neutrofil Ikan Lele turun pada P2 (0.1\%), P3 (0.3\%), dan P5 (0.7\%). Pada P0 Ikan Lele tidak diberikan perlakuan pengobatan menggunakan Ekstrak Buah Nanas sehingga Ikan Lele tersebut hanya mengandalkan kekebalan pada tubuh yang terdapat dalam tubuhnya sendiri sehingga proses penyembuhan membutuhkan waktu yang lebih lama.

Dosis ekstrak yang efektif untuk menurunkan jumlah total leukosit adalah P4 dengan dosis $0.5 \%$, dan pada P5 dengan dosis $0.7 \%$ leukosit mengalami kenaikan kembali. Hal ini diduga karena tingginya konsentrasi
Ekstrak Buah Nanas dan rasa asam dari Ekstrak Buah Nanas karena mengandung senyawa kimia antaranya asam folat, asam askorbat (vitamin C), saponin, tanin, bromelain, glukosid, flavonoid, dan beberapa mineral. Sesuai pendapat (Silaban \& Rahmanisa, 2016) Buah Nanas memiliki pH yang cukup asam, yaitu sekitar 3.0-3.5. Ekstrak Buah Nanas dengan dengan dosis $0.7 \%$ terlihat lebih keruh serta $\mathrm{pH}$ air diluar kisaran optimal dapat menyebabkan Ikan stress, mudah terserang penyakit, menyebabkan terjadinya gumpalan lendir didalam insang dan dapat menyebabkan kematian (Purnamasairi dkk, 2015), sehingga stress dan Ikanterserang penyakit lain dapat menyebabkan terjadinya leukositosis.

Dosis ekstrak yang efektif untuk menurunkan jumlah neutrofil adalah P5 dengan dosis $0.7 \%$, Kenaikan jumlah total leukosit dan neutrofil, disebabkan karena adanya infeksi bakteri dimana saat bakteri masuk kedalam tubuh akan diproses oleh makrofag yang ada didalam jaringan. Makrofag sebagai antigenprecenting cell akan memberikan pesan kepada limfosit, sehingga produksi dan proliferasi limfosit menjadi sel plasma akan meningkat. Kemudian sel plasma akan menghasilkan antibodi sebagai mekanisme kekebalan humoral (Haryani dkk, 2012). hal ini dikarenakan Buah Nanas memiliki senyawa antibakteri yaitu flavonoid. Senyawa aktif flavonoid dalam Ekstrak Buah Nanas memiliki kemampuan membentuk kompleks dengan protein sel bakteri melalui ikatan hidrogen. Struktur dinding sel dan membran sitoplasma bakteri yang mengandung protein, menjadi tidak stabil karena struktur protein sel bakteri menjadi rusak karena adanya ikatan hidrogen dengan flavonoid, sehingga protein sel bakteri menjadi kehilangan efektivitas biologionya, akibatnya fungsi permeabilitas sel bakteri terganggu dan 
e-ISSN 2685-8894; p-ISSN 2460-9773

Jurnal Vitek Bidang Kedokteran Hewan Vol.10, November 2020

sel bakteri mengalami lisis yang berakibat pada kematian sel bakteri (Purnamasairi dkk, 2015).

Pada jumlah total leukosit dan neutrofil Ikan Lele setelah perendaman Ekstrak Buah Nanas P1(Tanpa Ekstrak Nanas), terdapat perbedaan nyata dengan $\mathrm{P} 2(0.1 \%), \mathrm{P} 3(0.3 \%)$, P4(0.5\%), P5(0.7\%). Hal ini disebabkan karena Ekstrak Buah Nanas memiliki senyawa aktif meliputi : Flavonoid, Saponin, Tannin, Bromelin. Hal ini disebabkan karena Ekstrak Buah Nanas memiliki senyawa aktif yang tertinggi adalah Flavonoid (3.82\%) yang berperan penting menjadi antibakteri, menurut (Rohmana \& Wahyono, 2012). Tiga senyawa aktif lainnya pada Ekstrak Buah Nanas memiliki manfaat yang berbeda pula yaitu, Bromelin mengandung senyawa aktif $(2.05 \%)$, senyawa aktif yang menurut (Putri \& Yuanita, 2016), mempunyai efek antibakterial dan Tanin mengandung senyawa aktif $(2.56 \%)$. Menurut Marlin dkk (2018), akan bekerja merusak membran sel serta Saponin mengandung senyawa aktif $(3.16 \%)$ akan bertugas dengan cara menurunkan tegangan permukaan dinding sel bakteri Aeromonas hydrophila.

Peningkatan produksi sel darah putih akan menyebabkan neutrofil pada darah tepi meningkat hingga melebihi batas normal nilai presentase neutrofil. Neutrofil merupakan salah satu jenis sel darah putih penanda inflamasi atau peradangan. Neutrofil akan bekerja ketika terdapat sinyal dari hormon sitokin yang menunjukkan lokasi terjadinya inflamasi dalam tubuh sehingga terjadi peningkatan jumlah neutrofil pada darah tepi (Prihandari \& Muniroh, 2016). Umumnya jumlah neutrofil meningkat pada saat terjadi kasus penyakit yang disebabkan oleh bakteri karena neutrofil keluar dari pembuluh darah menuju daerah infeksi. Fungsi utama neutrofil adalah penghancuran bahan asing melalui proses fagisitosis, yaitu kemotaksis di mana sel berimigrasi menuju pratikel, perlekatan partikel pada sel, penelanan partikel oleh sel dan penghancuran partikel oleh enzim lisosom di dalam fagolisosom. Keluarnya neutrofil dari pembuluh darah pada saat terjadinya infeksi disebabkan karena adanya pengaruh rangsangan kimiawi ekternal atau kemotaksis (Rukyani dkk, 1997).

\section{KESIMPULAN}

Ekstrak Buah Nanas $0.5 \%$ efektif dapat menurunkan kadar leukosit pada Ikan Lele (Clarias batrachus) yang terinfeksi bakteri A.hydrophila dan $0,7 \%$ efektif dapat menurunkan kadar neutrofil pada Ikan Lele (Clarias batrachus) yang terinfeksi bakteri A.hydrophila

\section{REFERENSI}

Apriyanti, I., \& Septianingsih, D. B. (2007). Dalam Seluk Beluk Nanas dan Penanamannya. Bandung: Jasa Grafika Indonesia.

Bakhri, S. (2018). Analisis Jumlah Leukosit Dan Jenis Leukosit Pada Individu Yang Tidur Dengan Lampu Menyala Dan Yang Dipadamkan. Jurnal Media Analis Kesehatan, 83-91.

Haryani, A., Grandiosa, R., Buwono , I. D., \& Santika, A. (2012). Uji Efektivitas Daun Pepaya (Carica papaya) Untuk Pengobatan Infeksi Bakteri Aeromonas Hydrophila Pada Ikan Mas Koki (Carassius auratus). Jurnal Perikanan dan Kelautan, 218. 
e-ISSN 2685-8894; p-ISSN 2460-9773

Jurnal Vitek Bidang Kedokteran Hewan Vol.10, November 2020

Hayat, I. U., Suryanto, E., \& Abidjulu, J. (2015). Pengaruh Sari Buah Nanas (Ananas comosus (L.) Terhadap Aktivitas Antioksidan Pada Ekstrak Tongkol Jagung (Zea mays L.). jurnal ilmiah farmasi .

Hayat, I. U., Suryanto, E., \& Abidjulu, J. (2015). Pengaruh Sari Buah Nanas (Ananas comosus (L.) Terhadap Aktivitas Antioksidan Pada Ekstrak Tongkol Jagung (Zea mays L.). jurnal ilmiah farmasi , 5157.

Karlina, C. Y., Ibrahim, M., \& Trimulyono, G. (2013). Aktivitas Antibakteri Ekstrak Herba Krokot (Portulaca oleracea L.) terhadap Staphylococcus aureus dan Escherichia coli.

Kiswari, R. (2014). Hematology \& Transfusi. Jakarta: Penerbit Erlangga.

Mahasri, G., Widyastuti, P., \& Sulmartiwi , L. (2011). Gambaran Leukosit Darah Ikan Koi (Cyprinus carpio) yang Terinfestasi Ichthyophthirius multifiliis pada Derajat Infestasi yang Berbeda dengan Metode Kohabitasi. Jurnal Ilmiah Perikanan dan Kelautan , 91-96.

Mahasri, G., Widyastuti, P., \& Sulmartiwi, L. (2011). Gambaran Leukosit Darah Ikan Koi (Cyprinus carpio) yang terinfestasi Ichthyophthirius multifiliis pada Derajat Infestasi yang Berbeda dengan Metode Kohabitasi . Jurnal Ilmiah Perikanan dan Kelautan, 92.

Marlina, E., Harlia, E., \& Hidayati, Y. (2018). Efektivitas Limbah Buah Nanas (AnanasComosus) Sebagai Desinfektan Alami Pada Milk Can. Ilmu Ternak, 60.
Muslikha, Pujiyanto, S., Jannah, S. N., \& Novita, H. (2016). Isolasi, Karakterisasi Aeromonas hydrophila dan Deteksi Gen Penyebab Penyakit Motile Aeromonas Septicemia (MAS) dengan 16s rRNA dan Aerolysin Pada Ikan Lele (Clarias sp.). jurnal biologi, 1-7.

Nugraha, G. (2017). Panduan Pemeriksaan Laboratorium Hematologi Dasar. Jakarta: Cv. Trans Info Media.

Nurul Hidayah, d. M. Diktat Imunologi Veteriner. Surabaya.

Olga. (2014). Patogenisitas Bakteri Aeromonas hydrophila ASB01 Pada Ikan Gabus (Ophicephalus striatus). sains akuatik, 3339.

Preanger, C., Utama, I. H., \& Kardena, I. (2006). Gambaran Ulas Darah Ikan Lele di Denpasar Bali. Indonesia Medicus Veterinus

Prihandari, R., \& Muniroh, L. (2016). Jus Semangka Menurunkan Neutrofil Tikus Jantan Galur Wistar yang Terpapar Asap Rokok. Media Gizi Indonesia, 166-174.

Purnamasairi, L., Sasanti, A. D., \& Yulisman. (2015). Perendaman Ikan Lele Sangkuriang (Clarias sp.) Dalam Sari Buah Belimbing Wuluh Untuk Mengobati Infeksi Aeromonas hydrophila. Jurnal Akuakulutur Raw Indonesia , 82-93.

Purwaningsih, I. (2017). Potensi Enzim Bromelin Sari Buah Nanas (ananas comosus 1.) dlam meningkatkan kadar protein pada tahu. jurnal teknologi laboratorium , 39-46. 
e-ISSN 2685-8894; p-ISSN 2460-9773

Jurnal Vitek Bidang Kedokteran Hewan Vol.10, November 2020

Putri, R. M., Yuanita, T., \& Roelianto, M. (2016). Daya Anti Bakteri Ekstrak Kulit Nanas (Ananas comosus) Terhadap Pertumbuhan Bakteri Enterococcus faecalis. Conservative Dentistry Journal , 16.

Putri, R. M., Yuanita, T., \& Roelianto, M. (2016). Daya Anti Bakteri Ekstrak Kulit Nanas (Ananas comosus) Terhadap Pertumbuhan Bakteri Enterococcus faecalis. Conservative Dentistry Journal .

Putri, R., \& Yuanita, T. (2016). Daya Anti Bakteri Ekstrak Kulit Nanas (Ananas comusus) Terhadap Pertumbuhan Bakteri Enterococcus Faecalis. Conservative Dentisry Journal , 1-6.

Rohmana, Q. A., \& Wahyono, P. (2012). Pengaruh Sari Buah Nanas (Ananas comusus) Dan Lama Penyimpanan Terhadap Jumlah Koloni Bakteri Dan Kadar Protein Ikan Bandeng (Chanos chanos) Sebagai Sumber Belajar Dalam Perencanaan Pembelajaran Biologi Materi Kingdom Monera. Jurnal Pendidikan Biologi Indonesia , 60-70.

Rukyani, A., Silvia, E., Sunarto, A., \& Taukhid. (1997). Peningkatan Respon Kebal NonSpesifik Pada Ikan Lele Dumbo (Clarias sp.) Dengan Pemberian Imunostimulan. Jurnal Penelitian Perikanan Indonesia , 1- 10.

S, R. R., Nofrizal, \& Syofyan, I. (2017). Study On Catfish (Clarias batrachus) Behavior In The Capture Process BY PVC TRAP.

Salasia, S. I., Sulanjari, D., \& Ratnawati, A. (2001). Studi Hematologi Ikan Air Tawar. Biologi , 710-723.

Silaban, I., \& Rahmanisa, S. (2016). Pengaruh Enzim Bromelin Buah Nanas (Ananas comosus L.) terhadap Awal Kehamilan. 8085.
Sugiani, D., Taukhid, Purwaningsih, U., \& Lusiastuti, A. M. (2018). Vaksin Kering Beku Sel Utuh Bakteri Aeromonas hydrophila Untuk Pencegahan Penyakit Motile Aeromonads Septicemia Pada Ikan Lele, Nila, Dan Gurami. jurnal riset akuakultur .

Syaify, A. (2012). Pengaruh Level HBA1C Terhadap Fungsi Fagositosis Nutrofil (PMN) Pada Penderita Periodontitis Diabetika. 9397.

Thanikachalam, K., Kasi, M., \& Rathinam, X. (2010). Effect of Garlic peel on growth, hematological parameters and disease resistance againts Aeromonas Hydrophila inAfrican catfish Clarias gariepenus(Bloch) fingerlings. Asian Pasific Journal Of Tropical Medicine .

Yulinda, E. (2012). Analisi Finansial Usaha Pembenihan Ikan Lele Dumbo (Clarias gariepinus) di Kelurahan Lembah Sari Kecamatan Rumbai Pesisir Kota Pekanbaru Provinsi Riau. Perikanan dan Kelautan, 39.

Zharfan, R.S, Purwono, P, B \& Mustika, A. 2017. Antimicrobial Activity of Pinneaple (Ananas comosus L. MERR) Extract Againts Multidrug-Resistant of Pseudomonas aureginosa : An In Vitro Study. 118-123. 